\title{
Pemberdayaan KWT Ayu Tangkas pada Program Pengembangan Desa Mitra Mandiri Pangan
}

\section{(Empowerment of Ayu Tangkas Farmer Women's Groups in the Development Program of Food Self-sufficient Partner Village}

\author{
Ni Putu Sukanteri ${ }^{1 *}$, Yenny Verawati ${ }^{2}$, I Gusti Ayu Diah Yuniti ${ }^{3}$, I Made Suryana ${ }^{3}$ \\ 1 Program Studi Agribisnis, Fakultas Pertanian dan Bisnis, Universitas Mahasaraswati Denpasar, Jl. Kamboja No.11A, \\ Dangin Puri Kangin, Kec. Denpasar Utara, Kota Denpasar, Bali 80233. \\ 2 Program Studi Manajemen, Fakultas Ekonomi dan Bisnis, Universitas Mahasaraswati Denpasar, Jl. Kamboja No.11A, \\ Dangin Puri Kangin, Kec. Denpasar Utara, Kota Denpasar, Bali 80233. \\ 3 Program Studi Agroteknologi, Fakultas Pertanian dan Bisnis, Universitas Mahasaraswati Denpasar, Jl. Kamboja No.11A, \\ Dangin Puri Kangin, Kec. Denpasar Utara, Kota Denpasar, Bali 80233. \\ *Penulis Korespondensi: putusukanteri@unmas.ac.id \\ Diterima Januari 2020/Disetujui Februari 2021
}

\begin{abstract}
ABSTRAK
Desa Megati terletak di Kecamatan Selemadeg Timur, Kabupaten Tabanan, Bali memiliki posisi yang strategis, sehingga dapat menjadi potensi pengembangan desa mitra mandiri pangan berbasis sumber daya lokal. Tujuan kegiatan ini adalah untuk membina dan mendampingi kelompok wanita tani (KWT) desa Megati menuju Kelompok Mandiri Pangan. Pelatihan dan pendampingan kelompok industri rumah tangga dilaksanakan secara intensif agar menghasilkan produk yang siap dijual dan memiliki kualitas baik. Metode Participatory Research Action (PAR) merupakan suatu pendekatan partisipatif dan melakukan semua kegiatan secara bersama dengan masyarakat sasaran. Selain itu, menggunakan pendekatan alih teknologi guna memberikan inovasiinovasi baru dalam hal teknologi tepat guna yang sesuai dengan kebutuhan masyarakat sasaran. Hasil yang diperoleh dalam kegiatan pengabdian pada KWT Ayu Tangkas dilaksanakan di Desa Megati, Kecamatan Selemadeg Timur, Kabupaten Tabanan telah berjalan sebesar 100\% dalam mengolah hasil pertanian berupa ketela pohon menjadi berbagai kue olahan yang bernilai ekonomis. Mengolah ketela menjadi bolu gulung, bolu kukus, cake, donat, dan berbagai varian kue lokal dan nasional. Pelatihan penataan manajemen dan administrasi kelompok wanita tani meliputi menyusunan dokumen adminitrasi dalam bentuk buku kegiatan kelompok, buku daftar hadir kegiatan, dan buku laporan keuangan KWT Ayu Tangkas.
\end{abstract}

Kata kunci: mandiri pangan, Megati, pemberdayaan wanita tani

\begin{abstract}
Megati Village is located in East Selemadeg Subdistrict, Tabanan Districty. It has a strategic position, so that it can become a potential development for independent food partner villages based on local resources. The purpose of the activity is to foster and assist the group of women farmers (GWF) in the village of Megati towards the Self-Sufficient Food Group. Training and mentoring for home industry groups are carried out intensively in order to produce products that are ready to sell and have good quality. The Participatory Research Action (PAR) method is a participatory approach, carrying out all activities together with the target community. In addition, using a technology transfer approach, in order to provide new innovations in terms of appropriate technology in accordance with the needs of the target community. The results obtained in the service activities at GWF Ayu Tangkas carried out in Megati Village, East Selemadeg Subdistrict, Tabanan District have been running for $100 \%$ in processing agricultural products in the form of cassava into various processed cakes of economic value. Processing cassava into rolled sponge, steamed sponge, cake, donut, and various variants of local and national cakes. Training on management and administration of women groups includes the preparation of administrative documents in the form of a group activity book, an activity attendance book and a financial report book for GWF Ayu Tangkas.
\end{abstract}

Keywords: empowerment of female farmers, independent food, Megati 


\section{PENDAHULUAN}

Desa Megati adalah desa yang menjadi pusat pemerintahan Kecamatan Selemadeg Timur, Kabupaten Tabanan, Provinsi Bali. Secara demografi Desa Megati merupakan daerah yang mempunyai kondisi fisik landai dan beberapa daerah berdataran tinggi. Pada dataran tinggi, ketinggian \pm 400-500 mdpl, curah hujan relatif sedang. Kondisi iklim dan cuaca di wilayah ini sangat mendukung dilakukannya aktifitas pertanian, sehingga sebagian besar masyarakat bermatapencaharian sebagai petani. Petani di Desa Megati menggunakan dua pola pertanian, yaitu monokultur dan polikultur. Pola pertanian bertujuan membagi bagaimana pola penanaman dan manajemen pertanian. Membuat cara-cara dan metode untuk menanam sehingga panen akan melimpah dalam jangka waktu yang ditentukan (Hidayat 2015).

Struktur perekonomian Desa Megati masih bercorak agraris yang menitikberatkan pada sektor pertanian. Hal ini didukung oleh penggunaan lahan pertanian masih mempunyai porsi yang terbesar sebanyak $86,7 \%$ dari total penggunaan lahan desa. Sebanyak $60 \%$ penduduk bermatapencaharian pada sektor pertanian. Pada sektor ini komoditi yang menonjol sebagai hasil andalan adalah padi, kelapa, kakao, dan kopi.

Beberapa sektor ekonomi yang tergolong economic base dan menonjol di samping sektor pertanian adalah, perdagangan, industri rumah tangga, dan pengolahan. Pada sektor perdagangan meliputi pada pasar tradisional, warung, toko bangunan, dan jual beli hasil bumi. Sedangkan fasilitas pasar yang ada di Desa Megati, yaitu pasar desa. Pada sektor industri rumah tangga dan pengolahan termasuk pengolahan kue untuk upacara adat.

Sejalan dengan arah kebijakan di bidang ekonomi yang tercermin dalam RPJM Desa Megati maka tujuan dari program ini adalah memanfaatkan potensi sumber daya manusia dan sumber daya alam seoptimal mungkin untuk menghasilkan produk industri kecil dan kerajinan rumah tangga yang memiliki nilai tambah serta aktivitas perdagangan yang mampu menunjang pembangunan di desa.

Program pemberdayaan masyarakat di Desa Wisata Bumiaji yang di bangun dengan menata kawasan pedesaan dapat dijadikan sebagai rujukan dalam kegiatan kegiatan pemberdayaan masyarakat lainnya. Penataan tersebut dapat berupa lintasan bagi pejalan kaki, kawasan bersepeda di mana pengunjung dapat memperoleh pengalaman suasana dalam sajian desa wisata (Mustangin et al. 2017).

Desa wisata yang di kembangkan dalam upaya mengembangkan usaha mikro dan kecil yang dikelola oleh kaum perempuan untuk dapat meningkatan kesejahteraan keluarga melalui penambahan permodalan, bimbingan dan penyuluhan. Mengoptimalkan pengelolaan/penggunaan dana atau pendapatan yang berasal dari pemberian pemerintah daerah ataupun pusat dengan efektif dan efisien sesuai dengan arah kebijakan yang ditetapkan. Mendorong pengembangan usuha-usaha lain yang diakibatkan oleh pembangunan pariwisata sebagai dampak ikutannya, dengan memperhatikan adat, budaya, dan pelestarian lingkungan berdasarkan Tri Hita Karana.

Sebagai mitra dalam kegiatan pengabdian ini meliputi kelompok wanita tani (KWT) Ayu Tangkas merupakan mitra pengabdian masyarakat di Desa Megati. KWT Ayu Tangkas merupakan kelompok wanita tani yang bergabung dalam pengolahan hasil pertanian dalam bentuk kue-kue lokal dan pengolahan hasil pertanian dalam bentuk menu pendamping nasi. Kue yang diolah setiap hari merupakan kue yang dibutuhkan masyarakat setempat, selebihnya KWT ini menyediakan kue yang dibutuhkan untuk kebutuhan upacara. Masalah yang di hadapi KWT Ayu Tangkas adalah minimnya peralatan yang dimiliki untuk berproduksi, jenis kue yang di buat selalu monoton dan tidak ada variasi, dan pemasaran yang relatif rendah sehingga pemasaran hanya menunggu pemesaan saat upacara karena belum dikenal masyarakat luas.

Indentifikasi masalah menggunakan model partisipatory rural appraisal (PRA), yaitu dalam melaksanakan identifikasi masalah setiap program baik sumber daya manusia, sumber daya alam, sarana dan prasarana, perumusan program, dan pendanaan dilakukan secara terarah dengan berpihak dan melibatkan masyarakat. Dengan demikian dalam merumuskan masalah, mengatasi masalah, penentuan proses, dan kreteria masalah harus mengikutsertakan bahkan ditentukan oleh masyarakat/kelompok sasaran, diekspresikan melalui serangkaian metode partisipatif dan terutama visual. Bukti sampai saat ini menunjukkan validitas tinggi dan keandalan informasi yang dibagikan oleh masyarakat lokal (Chambers 1994). Penggunaan model pendekatan PRA sangat sesuai depakai dalam rangka pelaksanaan pemberdayaan masyarakat perdesaan. Prinsip, metode, dan aplikasi 
menguraikan penerapan metodologi PRA di bidang-bidang seperti penilaian partisipatif, analisis mata pencaharian berkelanjutan, pemantauan, dan evaluasi (Narayanasamy 2008).

Pelaksanaan kegiatan pengabdian pada KWT Ayu Tangkas di Desa Megati bertujuan agar anggota KWT mempunyai ketrampilan mengolah hasil panen berupa ketela pohon dan jagung menjadi kue bervariasi yang dapat dipasarkan, mampu mengolah kue dengan alat oven, KWT Ayu Tangkas mampu berproduksi dengan takaran yang sesuai sehingga rasa yang dihasilkan tidak berubah-ubah dan mampu meningkatan keterampilan serta pendapatan KWT Ayu Tangkas. Sinergisme dengan universitas panduan secara berkelanjutan menjadikan transfer teknologi dari universitas ke masyarakat secara langsung (Adawiyah 2018).

Tujuan pemberdayaan agar target yang akan dicapai jelas dan dapat dievaluasi. Selain program yang langsung mengarah kepada mitra, program peningkatan pembangunan pertanian bertujuan untuk meningkatkan produksi dan pemasaran hasil pertanian. Program peningkatan kapasitas masyarakat (pelatihan-pelatihan) yang bertujuan untuk meningkatkan sumber daya manusia di dalam mengolah potensi sumber daya alam dan hasil pertanian sehingga menghasilkan produk industri kecil yang memiliki nilai tambah. Program pengembangan ekonomi kerakyatan yang bertumpu pada mekanisme pasar.

Program pengembangan koperasi berbasis masyarakat dan lembaga keuangan mikro di desa yang bertujuan untuk dapat meningkatkan akses permodalan bagi usaha mikro dan kecil serta untuk dapat meningkatkan volume usaha ekonomi kerakyatan yang tumbuh di desa. Program pembangunan pariwisata yang tumbuh di desa yang bertujuan sebagai alternatif untuk memperluas kesempatan kerja dan mendorong pengembangan usaha-usaha lain yang diakibatkan oleh pembangunan pariwisata sebagai dampak ikutannya, dengan memperhatikan adat, budaya, dan pelestarian lingkungan berdasarkan Tri Hita Karana. Kegiatan prngabdian berupaya mencapai tujuan program pengabdian kepada masyarakat meningkatkan ketrampilan, pendapatan dan kesejahtraan anggota KWT Ayu Tangkas melalui program pengembangan desa mitra mandiri pangan berbasis sumberdaya lokal di Desa Megati.

\section{METODE PELAKSANAAN KEGIATAN}

\section{Waktu dan Lokasi Kegiatan}

Kegiatan pengabdian Masyarakat dalam Pengembangan Desa Mitra Mandiri Pangan dilaksanakan di Desa Megati, Kecamatan Selemadeg Timur, Kabupaten Tabanan telah dilaksanakan sejak bulan April 2019. Pemilihan lokasi merupakan atas pertimbangan bahwa Desa Megati sentra penghasil padi terluas di Kecamatan Selemadeg Timur serta penghasil ketela pohon dan jagung secara rutin pada musim kemarau.

Peserta yang terlibat dalam kegiatan adalah anggota Kelompok Wanita Tani (KWT) Ayu Tangkas terletak Desa Megati. Peserta yang terlibat sebagian besar bekeja sebagai petani dan pedagang produk olahan. KWT Ayu Tangkas merupakan mitra pengabdian masyarakat di Desa Megati yang bergabung sebagai anggota kelompok wanita tani dalam pengolahan hasil pertanian dalam bentuk kue lokal dan pengolahan hasil pertanian dalam bentuk menu pendamping nasi. Kue yang diolah setiap hari merupakan kue yang dibutuhkan masyarakat setempat, selebihnya KWT ini menyediakan kue yang dibutuhkan untuk kebutuhan upacara.

\section{Bahan dan Alat}

Alat yang diperlukan meliputi mesin penggiling ketela, kompor, panci pengukus, oven, pisau, waskom, mesin penggiling tepung, cetakan kue, dan sendok. Bahan-bahan yang digunakan dalam pelatihan ini melitupi tepung beras, ketela pohon, gula, santan, garam, jagung manis, agar rasa, dan margarine.

\section{Metode Pelaksanaan Kegiatan}

Gambaran umum desa mitra diperoleh melalui penjajagan pendahuluan. Informasi diperoleh dengan melakukan konsultasi, konsolidasi, dan observasi/wawancara terhadap key person yang ada pada setiap sasaran. Data yang diperoleh digunakan sebagai bahan penyusunan proposal yang dituangkan pada bagian analisis situasi dan kelayakan dari pelaksana, mitra, dan desa mitra.

Metode partisipatory rural appraisal (PRA) dilakukan melalui tahapan-tahapan sebagai berikut: mengumpulkan anggota KWT Ayu Tangkas untuk disosialisasikan tentang kegiatan yang dilakukan selama pelatihan. Selanjutnya mela- 
kukan wawancara terhadap anggota KWT untuk mengetahui masalah yang dihadapi dalam proses produksi produk dan kegiatan KWT. Setelah ditemukan masalah, dirangkum dan dirundingkan solusi yang tepat diterapkan untuk mengatasi masalah tersebut. Dilakukan diskusi kembali dengan anggota KWT mengenai kesepakatan terkait solusi yang diberikan untuk mengatasi malasah, selanjutnya permasalahan yang membutuhkan praktik pendampingan secara langsung dapat dilakukan secara bersama antara instruktur dan anggota KWT Ayu Tangkas. Selama proses pelatihan dan pendampingan dilakukan pula interaksi tanya jawab antara narasumber dan anggota untuk melakukan evaluasi.

Model technology transfer (TT) dilakukan agar anggota KWT Ayu Tangkas: 1) Menguasai prinsip-prinsip penerapan teknologi terutama yang berkaitan dengan pelatihan yang sedang/ akan dilaksanakan; 2) Jika teknologinya dirasakan terlalu rumit untuk menyelesaikan masalah/kebutuhan, maka ketua program mempunyai kewajiban untuk menyederhanakan melalui penerapan teknologi tepat guna (TTG); dan 3) menghasilkan produk melalui percontohan/demplot yang dapat menyelesaikan masalah/kebutuhan.

\section{Pelatihan, Pendampingan, dan Monitoring}

Metode pendekatan untuk meningkatkan kemampuan sumber daya manusi adalah pelatihan, pendampingan, dan monitoring. Metode ini diawali dengan pelatihan berupa teori, dilanjutkan dengan pendampingan dalam workshop dari teori yang diberikan untuk membuat desain produk atau proptoti peluaran, dan dilanjutkan dengan monitoring dan pendampingan dalam penerapan hasil workshop dalam uji coba terbatas dan mengarah ke kemandirian. Peningkatan keterampilan masya-rakat melalui pelatihan pengolahan ini diharapkan mampu mendorong kemajuan perekonomian masyarakat dan tumbuhnya industri rumah tangga di Desa Ambarketawang (Aji \& Pratiwi 2017).

Metode pemecahan masalah yang digunakan berupa pengenalan dan pelatihan pembuatan produk olahan ubi jalar ungu, pengemasan dan manajemen pemasaran melalui kegiatan ceramah, penyuluhan pelatihan pembuatan produk olahan ubi jalar ungu, serta pendampingan selama proses produksi sampai pemasaran. Hasil yang didapatkan bahwa kegiatan penyuluhan, pelatihan, serta pendampingan pembuatan produk-produk olahan ubi ungu meliputi: pengolahan menjadi pia, dodol, dan pie ubi jalar ungu berjalan dengan baik. KWT Merta sari dan Mekar Sari sudah mampu memproduksi produk olahan tersebut dengan baik. Pengemasan dan pelabelan pada produk pun sudah dapat dikerjakan dengan baik serta dihasilkan produk dengan identitas dan penampilan yang menarik. Selain itu, jiwa kewirausahaan meningkat dikalangan ibu-ibu KWT yang nantinya diharapkan dapat meningkatkan pendapatan dan kesejahteraan masyarakat Desa Bukian (Widarta et al. 2016). Melalui pelatihan, pendampingan, dan monitoring, diharapakan KWT Ayu Tangkas dapat meningkatkan ketrampilan, wawasan, dan pendapatan dalam pengelolaan pangan yang berasal dari sumber daya lokal menuju peningkatan pendapatan anggota KWT Ayu Tangkas.

\section{HASIL DAN PEMBAHASAN}

\section{Sosialisasi dan Pelaksanaan Kegiatan Pengabdian pada KWT Ayu Tangkas}

Kegiatan sosialisasi dilakukan setelah mendapat ijin dari Kepala Desa Megati, dilanjutkan dengan kegiatan sosialisasi mengenai kegiatan yang dilakukan. Sosialisasi diikuti oleh anggota KWT Ayu Tangkas secara antusias dan optimis kegiatan akan berjalan lancar. Anggota KWT terdiri dari 12 orang yang seluruhnya adalah ibu rumah tangga yang mengolah hasil pertanian yang dihasilkan dari lahan di Desa Megati dan sekitarnya. Gambar 1 menunjukkan sosialisasi kegiatan pengabdian masyarakat pada KWT Ayu Tangkas.

\section{Pelatihan dan Pengolahan Ketela Pohon pada Anggota KWT Ayu Tangkas}

Pelatihan dilakukan secara bertahap mulai dari pengenalan alat dan menyiapkan bahan yang diperlukan. Pelatihan dilakukan setiap dua minggu sekali. Pelatihan mengolah kue berbahan baku ketela pohon. Ketela pohon yang diolah dimulai dengan mengupas kemudian membersihkan ketela. Selanjutnya ketela dikukus sebelum diolah menjadi bolu maupun kue olahan yang lain.

Anggota KWT Ayu Tangkas mengolah ketelah pohon telah mempunyai keterampilan mengolah ketela menjadi bolu kukus, bolu gulung, getuk mentega manis maupun donat, bahkan dendeng daun singkong. Sebelum mengikuti pelatihan anggota KWT hanya mengolah ketela pohon menjadi keripik atau merebus dan di kukus. 
Gambar 2 menunjukkan anggota KWT Ayu Tangkas mengolah kue berbahan baku ketela pohon.

\section{Pelatihan Pembuatan Administrasi Kelompok}

Pelatihan yang diberikan kepada anggota KWT Ayu Tangkas selain mengolah berbagai olahan makanan, juga diberikan pelatihan dalam mengelola administrasi kelompok. Semenjak berdiri dan berjalan kegiatan pada KWT belum ditata dengan baik atau dikelola dengan baik. Setelah dilakukan pelatihan perlengkapan administrasi disusun arsiparis untuk mendokumentasikan kegiatan yang dilakukan dalam bentuk dokumen administrasi, meliputi buku tamu, buku kegiatan kelompok, dan buku kas. Pelatihan ini ditujukan untuk melihat kegiatan yang telah berlangsung maupun kegiatan yang dilaksanakan di waktu berikutnya agar kelompok lebih mudah melaksanakan evalusi internal.

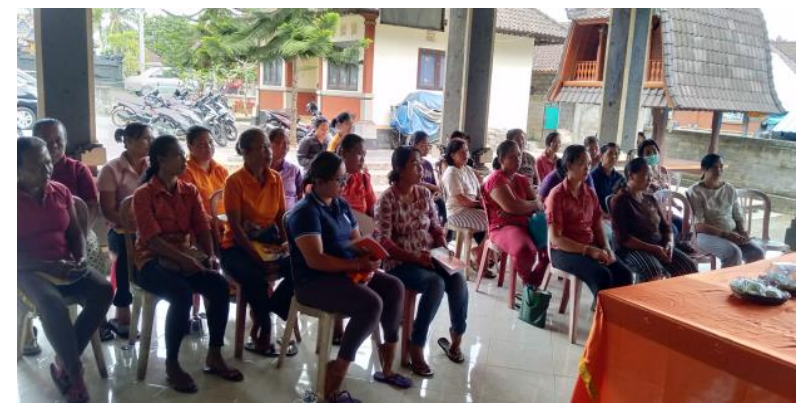

a
Gambar 3 menunjukkan pelatihan pembuatan administrasi KWT Ayu Tangkas.

\section{Hasil dan Luaran yang Dicapai terhadap Mitra Pengabdian pada Masyarakat}

Kegiatan pengabdian masyarakat dalam pengembangan desa mitra di Desa Megati Kecamatan Selemadeg Timur, Kabupaten Tabanan telah berjalan sejak bulan April 2019. Kegiatan tersebut meliputi mitra KWT Ayu Tangkas. Berdasarkan hasil evaluasi baik melalui survei, wawancara, dan pengamatan yang telah dilakukan pada KWT Ayu Tangkas terhadap perubahan pengetahuan dan ketrampilan anggota kelompok dapat dilihat pada Gambar 4.

Perubahan terhadap pengetahuan dan ketrampilan anggota KWT Ayu tangkas dalam mengolah hasil pertanian menunjukkan perubahan yang sangat baik, disebabkan oleh latihan yang diberikan oleh narasumber dapat diterima

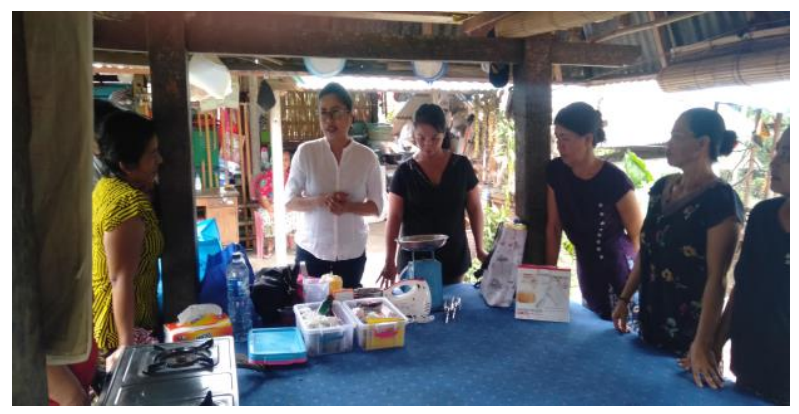

b

Gambar 1 a dan b) Sosialisasi kegiatan pengabdian masyarakat pada kelompok wanita tani Ayu Tangkas.

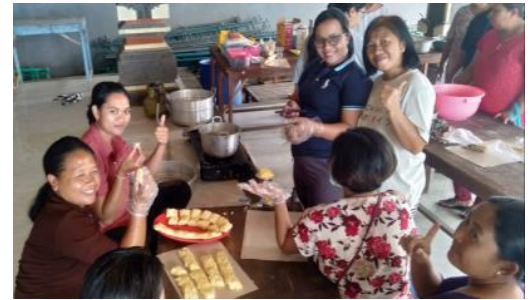

a

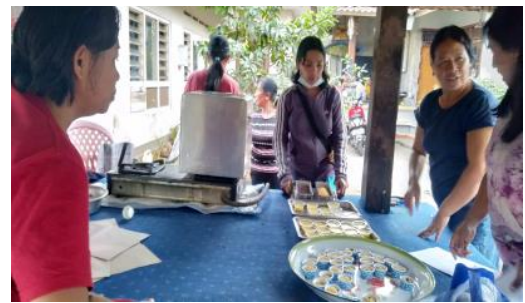

b

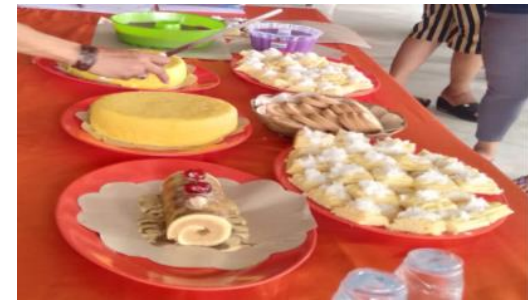

C

Gambar 2 a, b) Anggota kelompok wanita tani Ayu Tangkas mengolah kue berbahan baku ketela pohon dan c) Hasil olahan ketela pohon yang dihasilkan.

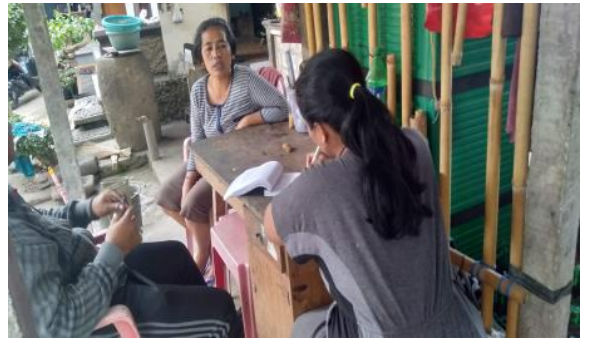

a

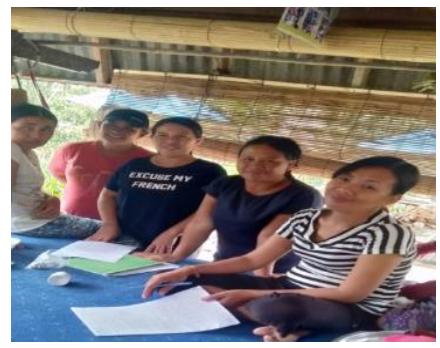

b

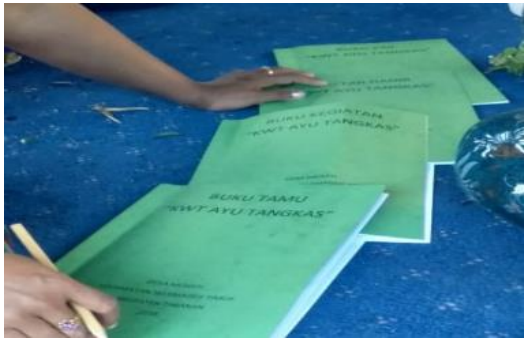

C

Gambar 3 a, b) Pelatihan pembuatan administrasi kelompok wanita tani Ayu Tangkas dan c) Buku catatan yang dihasilkan. 
Perubahan terhadap pengetahuan dan ketrampilan anggota kelompok wanita tani Ayu Tangkas mengolah hasil pertanian lokal

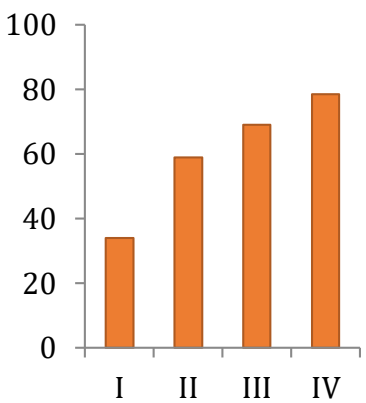

Perubahan terhadap pengetahuan dan ketrampilan anggota kelompok wanita tani Ayu Tangkas menggunakan oven dan mesin

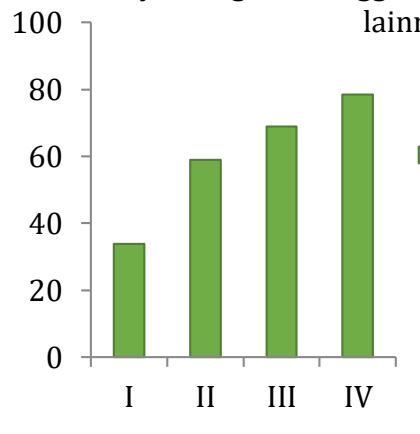

b pengetahuan dan KWT Ayu Tangkas $\square$ Perubahan terhadap pengetahuan dan ketrampilan anggota KWT Ayu Tangkas mengolah hasil pertanian lokal

a $\square$ Perubahan terhadap ketrampilan anggota menggunakan oven...

Gambar 4 Perubahan terhadap pengetahuan dan ketrampilan anggota kelompok wanita tani Ayu Tangkas setelah a) Pelatihan mengolah hasil pertanian local dan b) Pelatihan menggunakan oven dan mesin lainnya.

dan dapat dipraktikkan kembali oleh anggota di luar kegiatan pelatihan. Selain itu keberhasilan tersebut juga diimbangi oleh kerja sama yang baik antar anggota KWT yang mempunyai minat yang tinggi terhadap kemampuan mengaolah hasil bumi yang mereka hasilkan dengan harapan para ibu rumah tangga ini yang tergabung dalam KWT Ayu Tangkas dapat menambah penghasilan keluarga melalui menciptaan lapangan kerja sebagai industri rumah tangga yang terlatih dan terampil.

Perubahan pengetahuan dan keterampilan pada anggota KWT Ayu Tangkas diketahui dengan menggunakan metode quassy experimental dengan rancangan one group pretestposttest design. Responden akan diberikan tes sebelum pelatihan maupun setelah dilakukan pelatihan. Variabel bebas dalam penelitian ini adalah keikutsertaan anggota KWT dalam pelatihan mengolah hasil pertanian seperti tepung beras, jagung, dan ketela pohon.

Pengetahuan didefinisikan sebagai kemampuan untuk menghasilkan produk olahan bervariasi dari bahan tepung beras, jagung, maupun ketela pohon. Teknik pengumpulan data dilakukan dengan menggunakan kuesioner pengetahuan berupa pilihan benar atau salah. Responden diberikan lembaran sebelum pelatihan sesuai dengan pengetahuannya. Kemudian responden diberikan pelatihan dengan metode penyuluhan dan simulasi keterampilan. Setelah itu respoden akan diberikan kembali lembaran kuesioner setelah pelatihan (Sidqotie \& Saftarina 2020).

Berdasarkan pengabdian yang telah di laksanakan di KWT Ayu Tangkas, yaitu sebelum kegiatan pengabdian dilaksanakan, sebagian besar anggota KWT Ayu Tangkas belum mempunyai ketrampilan dalam mengolah hasil pertanian khususnya hasil panen meliputi jagung dan ketela pohon sehingga kebanyakan dijual dalam bentuk hasil panen segar. Produksi yang melimpah tidak menjamin kesejahteraan petani pembudidayanya. Hal ini disebabkan karena selama ini singkong dipasarkan dalam bentuk segar tanpa pengolahan lebih lanjut. Daun singkong yang masih muda juga dijual dalam satuan ikat sebagai sayuran. Bagi petani penjualan daun singkong dianggap sebagai hasil sampingan sehingga harga yang akan diterima tidak terlalu dipermasalahkan. Seperti halnya karakteristik hasil pertanian pada umumnya (Handayani \& Sundari 2016).

Setelah dilaksanakan pelatihan selama enam bulan didampingi oleh instruktur, ketrampilan anggota terlihat meningkat menjadi $80 \%$ telah mampu mengolah hasil panen menjadi olahan yang bervariasi dan tentunya mempunyai nilai tambah yang lebih besar. Adapun ketrampilan yang telah dikuasai oleh anggota KWT Ayu Tangkas, yaitu mengolah ketela menjadi bolu, pudding, kue vla, dan cake yang dapat dipasarkan sebagai variasi makanan olahan dalam industri rumah tangga anggota KWT Ayu Tangkas. Pengolahan ketela yang dihasilkan dari hasil pertanian di Desa Megati menjadi lebih bernilai dan meningkatkan minat masyarakat dalam mengkonsumsi ketela sebagai pangan berkualitas.

Selain ketrampilan dalam mengolah makanan, anggota KWT dikenalkan dan dilatih menggunakan alat-alat sederhana yang sebelumnya tidak pernah digunakan dalam mengolah dan memasak olahan tersebut, salah satunya adalah 
penggunaan oven, anggota KWT Ayu Tangkas mengolah pangan hanya menggunakan alat yang dimiliki dalam keluarga saja, setelah pelatihan mulai dikenalkan penggunaan alat-alat tertentu seperti timbangan yang digunakan untuk mengukur takaran yang pas dalam mengolah makanan. Oven digunakan untuk memanggang yang sebelumnya tidak pernah digunakan. Melalui pelahtihan anggota KWT memahami, mengerti, dan mengetahui cara menggunakan oven dalam mengolah makanan yang mereka inginkan.

Selama proses pelatihan merupakan proses untuk mengelola sumber daya manusia dari yang belum tahu atau belum mengetahui penataan administrasi menjadi mempunyai kemampuan menata administrasi kelompok secara sederhana. Tujuannya adalah untuk mengetahui perkembangan KWT baik dari segi manajemen maupun perubahan pendapatan. Gambar 5 menunjukkan perubahan pendapatan dan perubahan administrasi pada KWT Ayu Tangkas

Peranan wanita tani sangat besar dalam memberikan kontribusinya terhadap keluarga bukan saja sebagai penunjang bahkan sebagian besar sebagai tulang punggung keluarga dalam memenuhi kebutuhan ekonomi keluarga dan tugasnya sebagai ibu rumah tangga. Kondisi ini menjadi pendorong kearah peran aktif wanita tani memiliki keberdayaan, kemandirian, dan keswadayaan dalam upaya membantu suami meningkatkan taraf hidupnya (Ervinawati et al. 2015).

Perubahan pengetahuan dan ketrampilan pada anggota KWT Ayu Tangkas diketahui dengan menggunakan metode quassy experimental dengan rancangan one group pretestposttest design. Responden akan diberikan tes sebelum pelatihan maupun setelah dilakukan pelatihan. Variabel bebas dalam pengabdian ini adalah peningkatan pendapatan anggota KWT.
Teknik pengumpulan data dilakukan dengan menggunakan kuesioner pengetahuan berupa pilihan benar atau salah. Responden diberikan lembaran sebelum pelatihan sesuai dengan pengetahuannya. Kemudian responden diberikan pelatihan dengan metode penyuluhan dan simulasi keterampilan. Setelah itu respoden akan diberikan kembali lembaran kuesioner setelah pelatihan (Sidqotie \& Saftarina 2020).

Setelah di evaluasi secara keseluruhan dapat diketahui secara nyata bahwa dengan aktifnya KWT Ayu Tangkas dapat memberikan peningkatan pendapatan terhadap keluarga dan peningkatan pendapatan dalam pelaksanaan industri rumah tangga. Terlihat secara nyata mengalami perubahan yang cukup besar menunjukkan lebih dari 50\% KWT Ayu Tangkas telah memperoleh peningkatan pendapatan melalui kegiatan industri rumah tangga dan pendampingan dalam pengolahan pangan. Hal ini dapat dilihat dari catatan administratif yang telah dijalankan sejak pelaksanaan pendapingan yang dilakukan pada KWT Ayu Tangkas di Desa Megati, Kecamatan Selemadeg Timur, Kabupaten Tabanan.

\section{Kendala yang Dihadapi KWT Ayu Tangkas}

Rangkaian kegiatan pengabdian yang dilakukan meliputi sosialisasi, pelatihan, maupun pendapingan dari tim pelaksanan program pengabdian desa mitra Universitas Mahasaraswati Denpasar. Selama pelaksanaan kegiatan adapun kendala yang dihadapi, yaitu anggota KWT Ayu Tangkas masih ada yang absen saat dilakukan pelatihan. Kendala yang dihadapi juga memasarkan hasil olahan, dan menjaga mutu kue yang dihasilkan, sehingga perlu dilakukan pelatihan secara berlanjut untuk mengatasi kendala yang ada. Selain itu, kendala yang dihadapi anggota KWT Ayu Tangkas selama

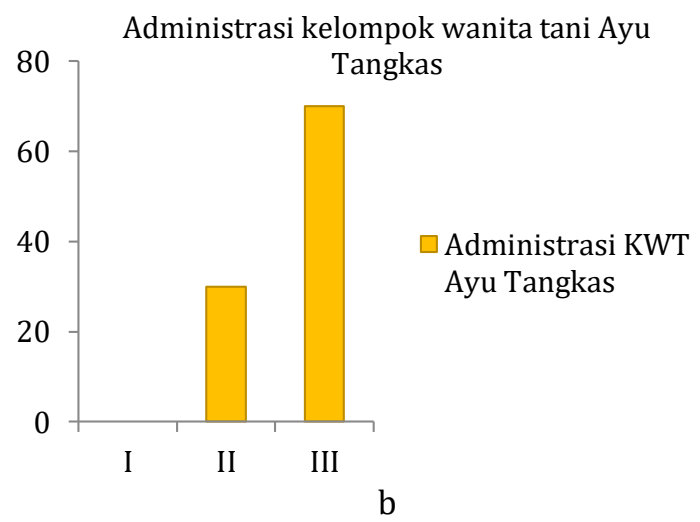

Gambar 5 a) Perubahan pendapatan dan b) Perubahan administrasi pada kelompok wanita tani Ayu Tangkas. 
pelaksanaan program adalah kedisplinan mengikuti pelatihan, kesulitan mengoperasikan mesin yang baru di gunakan selama pelatihan.

\section{SIMPULAN}

Kegiatan program pengembangan desa mitra yang dilaksanakan di Desa Megati, Kecamatan Selemadeg Timur, Kabupaten Tabanan telah $100 \%$ berjalan dengan capaian sebesar 100\% pada mitra KWT Ayu Tangkas. Kegiatan pada KWT Ayu Tangkas meliputi sosialisasi dan pelatihan pengolahan pangan yang dihasilkan dari hasil pertanian di Desa Megati dengan berbagai varian kue lokal dan nasional, pelatihan penataan manajemen dan administrasi kelompok. Manfaat program pengembangan desa mitra mandiri pangan adalah meningkatkan pengetahuan anggota KWT untuk menghasilkan variasi produk olahan dan peningkatan keterampilan dalam menggunakan oven.

Saran pada anggota KWT adalah harus disiplin dalam mengikuti pelatihan, dan mencoba mempraktikkan kembali bersama anggota setelah dilakukan pelatihan agar menguasai ketrampilan pengolahan produk maupun penggunaan oven dengan baik.

\section{UCAPAN TERIMA KASIH}

Ucapan terima kasih disampaikan kepada Anggota KWT Ayu Tangkas yang telah bersedia menjadi mitra dalam kegiatan pengabdian kepada masyarakat serta Kepala Desa Megati Kecamatan Selemadeg Timur Kabupaten Tabanan yang telah berpartisipasi dalam kegiatan ini dalam pelatihan dan pendampingan pengolahan produk olahan berbahan bakuberas dan non beras (ketela pohon).

\section{DAFTA PUSTAKA}

Adawiyah R. 2018. Strategi Pengembangan Badan Usaha Milik Desa (Bumdes) Berbasis Aspek Modal Sosial. Kebijakan Dan Manajemen Publik. 1(1): 1-15.

Aji OR, Pratiwi A. 2017. Pemberdayaan Kelompok Wanita Tani (KWT) Annaba' Dalam Diversifikasi Olahan Lidah Buaya Di Desa
Ambarketawang Kabupaten Sleman. Jurnal Pemberdayaan: Publikasi Hasil Pengabdian Kepada Masyarakat. 1(2): 401-404. https:// doi.org/10.12928/jp.v1i2.325

Chambers R. 1994. Participatory Rural Appraisal (Pra): Analysis of Experience. World Development. 22(9): 1253-1259. https://doi. org/10.1016/0305-750X(94)90003-5

Ervinawati V, Fatmawati, Indri LE. 2015. Peranan Kelompok Wanita Tani Perdesaan Dalam Menunjang Pendapatan Keluarga di Dusun Beringin Desa Sungai Rengas Kecamatan Sungai Kakap, Kabupaten Kubu Raya Provinsi Kalimantan Barat. Jurnal Tesis PMIS-UNTANPSS-2015. 1(1): 1-7.

Handayani SM, Sundari MT. 2016. Pemberdayaan Wanita Tani Melalui Pembuatan Keripik Belut Daun Singkong Di Kecamatan Jumantono Kabupaten Karanganyar. Jurnal Dianmas. 5(1): 23-34.

Hidayat MR. 2015. Kajian Pola Pertanian Dan Upaya Konservasi Di Dataran Tinggi Dieng Kecamatan Kejajar Kabupaten Wonosobo. [Thesis]. Semarang (ID): Universitas Negeri Semarang.

Mustangin, Kusniawati D, Islami NP, Setyaningrum B, Prasetyawati E. 2017. Pemberdayaan Masyarakat Berbasis Potensi Lokal Melalui Program Desa Wisata Di Desa Bumiaji. Sosioglobal: Jurnal Pemikiran Dan Penelitian Sosiologi. 2(1): 58-72. https:// doi.org/10.24198/jsg.v2i1.15282

Narayanasamy N. 2008. Participatory Rural Appraisal: Principles, Methods And Application. India (IN): SAGE Publications Pvt. Ltd.

Sidqotie C, Saftarina F. 2020. Perbedaan Pengetahuan Antara Sebelum dan Sesudah Pelatihan Mengenai Pentingnya Antenatal Care pada Kader Posyandu Desa Gunungtiga, Kecamatan Ulubelu, Kabupaten Tanggamus, Lampung. Jurnal Majority Medical Journal of Lampung University. 9(1): 8-11.

Widarta IWR, Wiadnyani AAIS, Puspawati NN. 2016. Pemberdayaan Kelompok Wanita Tani Ubi Jalar Ungu Di Desa Bukian, Kecamatan Payangan Kabupaten Gianyar Melalui Ipteks Tepat Guna. Buletin Udayana Mengabdi. 15(2): 168-178. 